\title{
Miranda
}

Revue pluridisciplinaire du monde anglophone /

Multidisciplinary peer-reviewed journal on the English-

speaking world

5 | 2011

South and Race / Staging Mobility in the United States

\section{Tom Dunne and William L. Pressly, James Barry, 1741-1806: History Painter}

\section{Muriel Adrien}

\section{OpenEdition}

\section{Journals}

\section{Electronic version}

URL: http://journals.openedition.org/miranda/2706

DOI: $10.4000 /$ miranda.2706

ISSN: 2108-6559

Publisher

Université Toulouse - Jean Jaurès

\section{Electronic reference}

Muriel Adrien, "Tom Dunne and William L. Pressly, James Barry, 1741-1806: History Painter", Miranda

[Online], 5 | 2011, Online since 29 November 2011, connection on 16 February 2021. URL: http:// journals.openedition.org/miranda/2706 ; DOI: https://doi.org/10.4000/miranda.2706

This text was automatically generated on 16 February 2021.

\section{c.) (i) (2)}

Miranda is licensed under a Creative Commons Attribution-NonCommercial-NoDerivatives 4.0 International License. 


\title{
Tom Dunne and William L. Pressly, James Barry, 1741-1806: History Painter
}

\author{
Muriel Adrien
}

\section{REFERENCES}

Tom Dunne and William L. Pressly, James Barry, 1741-1806 : History Painter (Farnham : Ashgate, 2010), 268 p, ISBN 9780754666349

Despite the four books James Barry (1741-1806) authored, and despite his reputation as Britain's greatest history painter, his achievements were given scant attention until the second half of the twentieth century. One of the reasons may be that his oeuvre is sophisticated and limited (33 pictures), including six murals, which of course cannot be traded on the art market. But this edited collection lifts the veil on many other aspects of Barry's career, suggesting why his work has long remained neglected. The bicentennial of his death in 2006 was the opportunity to engage with his art anew through a major exhibit in Cork, Ireland, Barry's hometown, and new research by Pressly on Barry's magnum opus, The Adelphi series. This edited volume publishes the conference papers given on the occasion of the bicentennial Cork exhibition and offers much needed scholarship on an overlooked artist, given the quality of his ambitious oeuvre.

In an introductory chapter, Tom Dunne says that Barry was a much more radical and fervent believer in the genre of history painting than Reynolds was himself, and he loudly resented the national development of lesser genres at the expense of the grand style. Barry severely criticized Reynolds for abandoning high art in favour of lukewarm and debased commercial painting, although he did take up with him again later. His uncompromising attitude accounts for his expulsion from the Royal Academy in 1799. Barry commended the ideal classical Greek model, thinking the values it conveyed would transform society into a "republic of taste". His Progress of Human Culture encoded a pro-Catholic subtext for which he later felt the need to provide an 
explanation. This unswerving commitment put him at odds with the adverse British art world whose market was sustained by other genres. Dunne then mentions how Michael Phillips shed new light on Barry as printmaker. Barry's radicalism and principled temperament owed him the admiration of Blake, as well as his Fuseli-like attraction for Miltonic themes of exile and expulsion. But Fuseli was more cynical and pragmatic than Barry who remained ever the vocal staunch idealist.

3 David Solkin focuses on Barry's critical legacy, and starts by saying that Barry's entombment in St Paul next to Reynolds testifies to his recognition as one of the leading figures of British art. Yet, during his lifetime, he attracted enemies and admirers alike. Some viewed his lack of social polish and worldly graces as consistent with his dedicated pursuit of artistic ambitions, impervious to the requirements of social manners. He antagonized more than one, including Edward Edwards who did not spare him in his Anecdotes of Painters who have resided or been born in England. Solkin then gives an overview of Barry's legacy, and how opinion slowly shifted in his favour with the publication of Cunningham's book in 1829-30, and then WB Sarfield Taylor's, for whom his reputation as odd man out or pretentious misanthrope was less due to his own flawed character than to the obtuse opinions of his contemporaries, and finally the Redgraves' work, who lauded Barry's talent at the expense of Benjamin West.

4 Martin Myrone's chapter starts and ends with Richard Payne Knight's denigration of Barry, eventually saying that his alienation from the art world might have in fact worked in favour of the later appreciation of his art. Barry was deprecatory of Northern art, deemed trivial and mundane, and called for the pursuit of nobler artistic aims-"hairbreadth niceties". Myrone analyses the gendered connotations of his argument, that one may find in Burke and Gilpin's writings as well-but this strategy of naturalising his line of defence (the pure artist detached from any mercenary concern) is self-defeating in that it resorts to culturally constructed concepts of gender. Barry's stay on the continent coincided with Diderot declaring that the French art was much in need of the expression of heroic sentiments, rather than the dull sentimental degenerate effeminate contemporary productions, a statement that was picked up by Barry, who also thought French art effete and corrupt, and preferred to take Poussin and Le Sueur as models. Yet Barry chose to depict less narrative and fewer figures, whom he endowed with emblematic significance. Burke suggested he concentrate on the anatomical linear and outlined figure rather than composition and tonal modelling, which he did with the probable aid of devices such as the camera obscura. Myrone then dwells on Barry's self-destructive and abrasive pretentiousness, which he says might have been necessary to his art.

5 Fionnuala McManamon's article focuses on Barry's preference for history painting, in spite of Burke's advice to turn to the lucrative career of a portrait painter. Much to Barry's displeasure, demand for history painting was lesser than for dainty decorative works-the frivolous agreeable "petite manière" (Boucher, Pierre, Natoire, Lemoyne...) - , but history painting slowly resurfaced in the 1770 s thanks to a more active political context. Barry's feelings were not unlike those of eminent French commentators such as Diderot or Caylus; Le Sueur, Poussin and others of the kind were high on his list of favourites and he fervently copied them. Contemporary works Barry did hold in high esteem were the Jansenist-inspired paintings of Restout, in that they agreed with Barry's belief that art should promote the civil humanist ideal and the pursuit of virtue 
and common good. Barry was very sceptical about the quality standard of the teaching by an Academy, given his experience at the Parisian Academy of St Luke.

6 Margaret Lind next analyses Barry's intentions when painting his Venus Rising from the Sea. Barry sought to emulate Apelles's lost work, as well as Raphael, Titian and his contemporaries Reynolds and West (1765), but tried to confer to his painting an intellectual status by drawing on Titus Lucretius Carus's text on Venus and Homers' Hymn to Venus. Acutely aware (and a little anxious) that his work ambiguously retained sensual and lustful appeal, he hoped to elevate it by depicting a Venus that would inspire a moral aspiration to refined love and virtue, in line with Shaftesbury's ideas about history painting. Later versions, such as a stipple engraving published by Boydell, gave it a feminine decorative bent which Barry probably disapproved of.

7 In the following essay, Martin Postle studies the relationship of Barry and Reynoldswho had met through the agency of a mutual friend, Burke-that is, their growing personal estrangement and enmity and ensuing reconciliation. The first rift occurred during the abandoned scheme of 1773 to decorate St Paul, introduced by Reynolds to the General Assembly, although it had been Barry's initial idea. Moreover, Barry blamed the debacle on Reynolds. It was probably Barry who, under the pseudonym of Fabius Pictor, wrote a press critique questioning Reynolds's qualifications as history painter. Furthermore, when Barry produced his painting of King Lear-a patriarchal archetype and political model, contrasting with Reynolds's more prosaic Ugolino-, it was to show, in intaglio, his diverging views with the painter. However, when Reynolds resigned after his fellow Academicians refused to appoint the Italian architect as an Associate Academician and Professor of Perspective, under the pretext that he was a foreigner, the Irish radical Barry performed a volte-face: not only did he support Reynolds then, but he also posthumously promoted his art, and characterized him usefully (albeit incorrectly) as a radical and revolutionary figure who had opposed the cabal of the compromised and lukewarm Royal Academy, and who had assigned him to defend the true aims of the Academy. Both now rest next to each other in St Paul, ironically.

8 Asia Haut then explores the symbolic reasons behind Barry and Fuseli's depiction of scenes from Milton's Paradise Lost (1667). Both born in 1741, both foreigners having emigrated to England 1764, before sojourning in Italy, Barry and Fuseli also both found in the Miltonic work-championed as the embodiment of English artistic achievementsimultaneously a way to become assimilated and a way to remain unassimilated, since the theme of exile permeates the text. Satan-as the uprooted archangel and the archetypical genius-became a central persona in their works. For Fuseli, he typified the refusal of a father figure or of any form of artistic lineage, and for Barry, he typified the rejection of the monotheistic model of creativity. In the late 1770s, the political reading of Paradise Lost and the greater attention to Milton's republican ideas caused interest in his work to become increasingly suspicious in England; but the political overtones of this work encouraged the two artists all the more to depict the Satanic character who represented rebellious challenge to artistic and monarchical authority.

David Bindman goes over the representations of envy by Blake and Barry, who both thought they were victims of the envy of other Academicians-hence their ostracized status and their misery. Barry was indeed for Blake the exemplum virtutis in the defense of high art against the malevolence of other Academicians (except Fuseli), and must have been all the more convinced of it by his friend's paranoid discourse. But their 
depictions of Satan as emblematic of envy per se can also be accounted for by the fact the British tradition, stemming from Shakespeare and Milton, granted the fallen archangel a highly prominent place.

10 John Barrell starts by giving an overview of what historians have said about Barry's politics, and whose ideas Barry followed or rejected. Barrell assesses Barry's political opinions in his Letter to the Society of Arts (1793) and the two editions of the Letter to the Dilettanti Society (1798-99), and says they are difficult to pin down as they were intricately mingled with his views about the Royal Academy. Indeed, both were often confused and lumped together in his mind: Barry believed a society that defended high art would also naturally defend the civil rights of its members as well as Christianity as the basis of civil liberties, all of which partook of the same spirit. Barrel revises Barry's republicanism and refutes his anti-monarchism, at least in Britain, saying that he was highly respectful of George III-the noble patron of the arts, according to him-and that he held the same view of Charles I. He did depart from mainstream Whiggism though, in that he believed the harbingers of civil liberties harked back further than the Whigs would have it, and were to be found in the Catholic resistance to Henry VIII (Thomas More...). Moreover, Barry seems to equate civil liberties with freedom of religion and to overlook other civil liberties. As for his opinion on the French revolution, Barry said Britain should not interfere with the will of the French, but did not totally adhere to the Foxite Whigs' stance as he deplored the secular character of the new state. However,-and this is more surprising, says Barrell-he approved the civil constitution of the clergy, as the Church in France needed to be reformed, so that Christianity be once again the foundation of society's respect of the natural and human rights. Barrell suspects that the argument of Barry's political ideas was but a pretext of Farington's to expel him. Barry upset him as he was openly and publicly criticizing the policies of the Royal Academy, and not least Farington's pension scheme which he believed would lead to further corruption.

11 Liam Lenihan examines Barry's position as regards neoclassicism, and describes how he challenged some of its tenets, in that he preferred an art that was inclusive of the imagination and sensibility of feeling, while acknowledging the power of reason and the need for art to attain universality stripped of particularity. A case in point is his representation of Minerva, which bridges sensibility and understanding. This position is in line with Reynolds's discourses, which Blake despised, but he never disparaged Barry, his former teacher. Lenihan then moves on to Mary Wollstonecraft's reaction to Burke's gendering of the aesthetic experience, and tries to connect their ideas with Barry's writings.

With the help of William Henry Curran's colourful testimony in the New Monthly Magazine (1823) and the auction sale records of his property in 1807, Michael Phillips very minutely endeavours to describe James Barry's seemingly rundown house and studio in the fashionable artistic area of Castle Street, Oxford Market. He also recalls how long it took Barry to complete The Birth of Pandora and the Self-Portrait as Timanthes, both acting as pendants in his studio.

William Pressly analyses Barry's Crowning the Victors at Olympia, the principal focus of the series of murals for the Great Room of the Society of Arts-for which he was given unprecedented control and authority. After giving a very detailed account of the characters who feature on the painting, Pressly argues that the scene was a way for Barry to promote an event where the stimulus of glory leads to public virtue, perhaps 
serving as a model for the Society of Arts. In the same revival vein, Barry's close friend, Giuseppe Baretti, commissioned music for performances of Horace's Carmen Secularepoems for a ritual festival celebrating the foundation of Rome-and for which Barry drew the ticket of admission. But even more interestingly, Pressly decodes the Christian subtext embedded in the picture, be it through the analogy between the temperate athlete and the incorruptible Christian, or the use of laurel crowns for champions as well as for martyrs, or the classical procession reminiscent of the Pope carried in his sedia. Religious underpinnings can also be found in other paintings of Barry's, such as Universal History or Commerce or The Triumph of the Thames. Of course, the meanings were hidden so as to escape the Society's probable censorship, but they were so well concealed that his audience failed to grasp it-which caused Barry's frustration ultimately.

In a very rich penultimate chapter, Daniel Guernsey reflects on the meaning of the added presence of the French Catholic theologian and Gallican Church supporter of Louis XIV, Bossuet, in Barry's mural for the Society of Arts (1777-84). On these murals which chart the evolution of Western civilization from Ancient Greece to eighteenthcentury England and America, Barry kept adding and retouching the murals until his death in 1806. When he added Bossuet-whose writings insist on Protestantism as a destructive anarchical force throughout history-, Barry wanted to stress the negative "Protestant-related" origin and impact of the Reformation, the Enlightenment and the French Revolution. Furthermore, the mural shows that Barry evolved from a standpoint where he identified himself with Protestant Dissenters of the American Revolution and their millenarian expectations (especially William Penn, who is foregrounded in the painting)-in line with the liberal religious and economic views of the Society of Arts-to a shift in allegiance to the Catholic Counter-Revolutionary order between 1793 and 1801 (with the addition of Bossuet), which enabled him to challenge the "Protestant ascendancy" (as he termed it) over his beloved Ireland.

In the concluding chapter, David Allan first goes over the multiple redecoration schemes of the Great Room of the Society of Arts-whose function also evolved-and the subsequent transformations and cleaning (or not) of Barry's murals. He also mentions how Barry had to wait for many years before he could gain recognition (1799) and payment from the Society. In a second part, Allan recalls how Barry had fallen into oblivion until scholars in the 1940s pioneered research work to give an in-depth reappraisal of the artist.

16 In re-examining and assessing James Barry's contribution to the history of art in the light of the history of his own times, this collection of scholarly chapters contributes to establishing fully the recognition of the artistic talent of James Barry-who was far too often dismissed simply as a reputedly eccentric and outlandish artist. The book is undoubtedly an erudite and highly valuable authoritative reference book for students and scholars who want to look into Barry's achievements. 


\section{INDEX}

Keywords: French revolution, neoclassicism, Protestantism, Catholicism, Pandora, Timanthes, Paradise Lost, Foxites, Satan, Cork, Royal Academy, whiggism, King Lear, Ugolino, camera oscura, St Luke's academy, Venus, St Paul's cathedral, Greek art, murals, Grand Manner, printmaking, Society of Arts

Mots-clés: révolution française, néoclassicisme, protestantisme, catholicisme, Pandore, Timanthes, Le Paradis perdu, Foxites, Satan, Cork, Royal Academy, Whigs, Roi Lear, Ugolino, camera oscura, Académie de St Luc, Vénus, Cathédrale St Paul, art grec, peinture murale, grande manière, petite manière, gravure, Society of Arts

\section{AUTHORS}

\section{MURIEL ADRIEN}

Maître de Conférences

Université Toulouse 2 - Le Mirail

muriel.adrien@univ-tlse2.fr 